Original article

\title{
Contributions to the knowledge of hard ticks (Acari: Ixodidae) in Colombia
}

Fredy A. Rivera-Páez ${ }^{\mathrm{a}, \mathrm{e}}$, Marcelo B. Labruna ${ }^{\mathrm{b}}$, Thiago F. Martins ${ }^{\mathrm{b}}$, Jorge E. Perez ${ }^{\mathrm{c}}$, Gabriel J. Castaño-Villa ${ }^{\mathrm{d}}$, Paula A. Ossa-López ${ }^{\mathrm{e}}$, Carlos A. Gil ${ }^{\mathrm{e}}$, Bruno Rodrigues Sampieri Hector J. Aricapa-Giraldo ${ }^{g}$, Maria I. Camargo-Mathias ${ }^{\mathrm{a}, *}$

a Departamento de Biologia, Instituto de Biociências, UNESP - Universidade Estadual Paulista, Avenida 24-A, 1515, Bairro Bela Vista, Rio Claro, SP, CEP13506-900, Brazil

${ }^{\mathrm{b}}$ Departamento de Medicina Veterinária Preventiva e Saúde Animal, Faculdade de Medicina Veterinária e Zootecnia, Universidade de São Paulo-USP,Av. Prof. Orlando

Marques de Paiva, 87, CEP 05508-000, Cidade Universitária, São Paulo, SP, Brazil

c Grupo de Investigación BIOSALUD, Departamento de Ciencias Básicas para la Salud, Facultad de Ciencias para la Salud, Universidad de Caldas, Calle 65 No. 26-10

Apartado Aéreo 275 Manizales, Caldas, Colombia

d Grupo de Investigación GEBIOME, Departamento de Desarrollo Rural y Recursos Naturales, Facultad de Ciencias Agropecuarias, Universidad de Caldas, Calle 65 No. 26-

10 Apartado Aéreo 275 Manizales, Caldas, Colombia

e Grupo de Investigación GEBIOME, Departamento de Ciencias Biológicas, Facultad de Ciencias Exactas y Naturales, Universidad de Caldas, Calle 65 No. $26-10$ Apartado Aéreo 275 Manizales, Caldas, Colombia

${ }^{\mathrm{f}}$ Universidade Estadual de Campinas, Museu de Zoologia, R. Charles Darwin s/n, cidade universitária, Campinas, SP, Brazil

g Departamento de Salud Animal, Facultad de Ciencias Agropecuarias, Universidad de Caldas, Calle 65 No. 26-10 Apartado Aéreo 275 Manizales, Caldas, Colombia

\section{A R T I C L E I N F O}

\section{Keywords:}

Amblyomma mixtum

Molecular analyses

Neotropical region

Rhipicephalus sanguineus

\begin{abstract}
A B S T R A C T
The known tick fauna of Colombia includes 58 species (15 Argasidae and 43 Ixodidae). To add to the knowledge of the biology of ticks in Colombia, hard ticks (Ixodidae) were collected from domestic animals or vegetation during 2014-2016 in 10 of Colombia's Departments. Ticks were identified to species through morphological examinations. Taxonomic identification was confirmed for some specimens by molecular methods, including phylogenetic analyses inferred from three tick genes (cytochrome c oxidase, 16S rDNA, second internal transcribed spacer). A total of 1745 tick specimens encompassing 8 species were collected. Overall, 5 tick species were recorded on cattle [Amblyomma dissimile, Amblyomma mixtum, Dermacentor nitens, Rhipicephalus microplus, Rhipicephalus sanguineus sensu lato (s.1.)], 5 on dogs (Amblyomma maculatum, Amblyomma ovale, Amblyomma varium, $R$. microplus, $R$. sanguineus s.l.), 3 on horses (A. mixtum, D. nitens, $R$. sanguineus s.1.), 3 on donkeys (A. mixtum, D. nitens, $R$. microplus), 1 on pig (D. nitens), and 2 from vegetation (A. mixtum, A. dissimile). This included the first records of $A$. mixtum from two Colombian Departments, indicating that the distribution of this tick in Colombia may be broader than currently known. Phylogenetic analyses confirmed that $R$. sanguineus s.l. specimens from 8 Departments belong to the "tropical species". Moreover, Colombian specimens of A. maculatum formed a large clade with GenBank sequences of $A$. maculatum and A. triste, although some Colombian specimens grouped with $A$. maculatum from the United States while others grouped with $A$. triste from Brazil. Significant polymorphisms were observed between specimens of $A$. ovale or $D$. nitens; for the former species, it is noteworthy that two distinct clades were observed. Our study provides new records for 8 tick species parasitizing domestic animals in Colombia, including species with veterinary and medical importance in the Neotropical region, such as R. microplus, R. sanguineus, D. nitens, A. mixtum, and A. maculatum. Noteworthy, we provide the first record of A. varium infesting a domestic mammal.
\end{abstract}

\section{Introduction}

The World's tick fauna currently includes 939 species of three families: Ixodidae (727 species), Argasidae (211 species) and Nuttalliellidae (1 species). Nearly one-fourth of these species are known to occur in the Neotropical region (Barros-Battesti et al., 2006; Hornok et al., 2016; Labruna et al., 2016; Muñoz-Leal et al., 2016; Apanaskevich and Bermúdez, 2017; Ash et al., 2017; Muñoz-Leal et al., 2017; Chitimia-Dobler et al., 2017; Guo et al., 2017; Nava et al., 2017). Broad-scale studies on ticks occurring in Colombia have been scarce (Osorno-Mesa, 1940; López and Parra, 1985). According to the last review of Neotropical ticks (Guglielmone et al., 2003), the following

\footnotetext{
* Corresponding author.

E-mail address: micm@rc.unesp.br (M.I. Camargo-Mathias).
} 
Table 1

Localities in Colombia where ticks were collected in the present study.

\begin{tabular}{lll}
\hline Locality number $^{\mathrm{a}}$ & Municipality & Department \\
\hline 1 & Leticia & Amazonas \\
2 & Medellín & Antioquia \\
3 & Arauca & Arauca \\
4 & Fortul & Arauca \\
5 & Saravena & Arauca \\
6 & San Jacinto & Bolívar \\
7 & Dorada & Caldas \\
8 & Neira & Caldas \\
9 & Norcasia & Caldas \\
10 & Nunchía & Casanare \\
11 & Yopal & Casanare \\
12 & Puerto Salgar & Cundinamarca \\
13 & San Juan de Arama & Meta \\
14 & Ibagué & Tolima \\
15 & Saldaña & Tolima \\
16 & Cali & Valle del Cauca \\
17 & Restrepo & Valle del Cauca \\
\hline
\end{tabular}

tick species are known to occur in Colombia: Argasidae (15 species) Antricola mexicanus Hoffmann, 1958, Argas magnus Neumann, 1896, Argas miniatus Koch, 1844, Ornithodoros azteci Matheson, 1935, Ornithodoros brodyi Matheson, 1935, Ornithodoros furcosus Neumann, 1908, Ornithodoros hasei (Schulzei, 1935), Ornithodoros marinkellei Kohls, Clifford and Jones, 1969, Ornithodoros marmosae Jones and Clifford, 1972, Ornithodoros peropteryx Kohls, Clifford and Jones 1969, Ornithodoros puertoricensis Fox, 1947, Ornithodoros rossi Kohls, Sonenshine and Clifford, 1965, Ornithodoros rudis Karsch, 1880, Ornithodoros talaje (Guérin-Méneville, 1849), and Ornithodoros yumatensis Cooley and Kohls, 1941; Ixodidae (38 species): Amblyomma auricularium (Conil, 1878), Amblyomma cajennense (Fabricius, 1787), Amblyomma calcaratum Neumann, 1899, Amblyomma coelebs Neumann, 1899, Amblyomma crassum Robinson, 1926, Amblyomma dissimile Koch, 1844, Amblyomma geayi Neumann, 1899, Amblyomma humerale Koch, 1844, Amblyomma longirostre (Koch, 1844), Amblyomma maculatum Koch, 1844, Amblyomma multipunctum Neumann, 1899, Amblyomma naponense (Packard, 1869), Amblyomma neumanni Ribaga, 1902, Amblyomma no-

${ }^{\text {a }}$ localities indicated in.
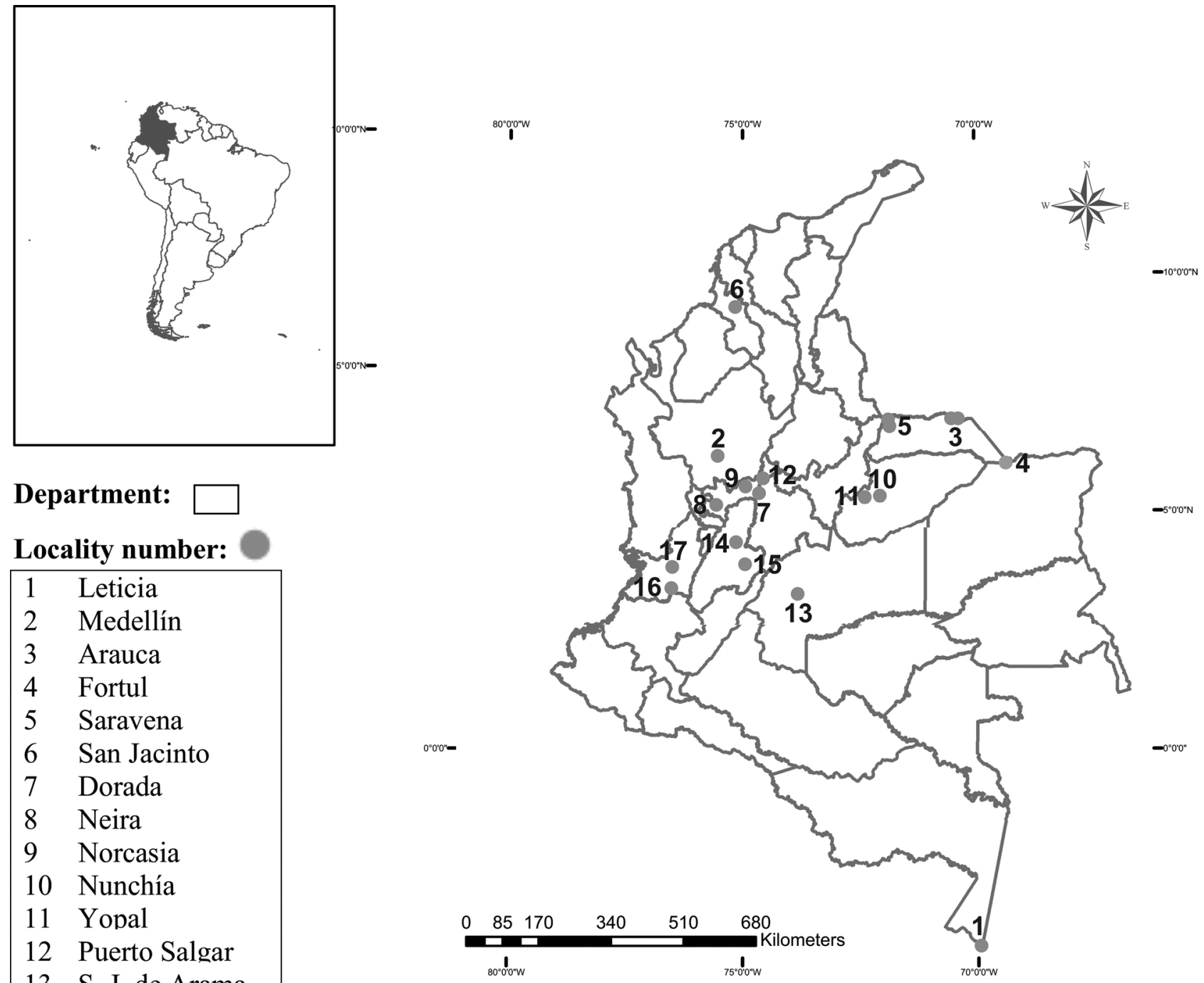

Department:

Locality number:

\begin{tabular}{|ll|}
\hline 1 & Leticia \\
2 & Medellín \\
3 & Arauca \\
4 & Fortul \\
5 & Saravena \\
6 & San Jacinto \\
7 & Dorada \\
8 & Neira \\
9 & Norcasia \\
10 & Nunchía \\
11 & Yopal \\
12 & Puerto Salgar \\
13 & S. J. de Arama \\
14 & Ibagué \\
15 & Saldaña \\
16 & Cali \\
17 & Restrepo \\
\hline
\end{tabular}

Fig. 1. Geopolitical map of Colombia showing the localities where ticks (Acari: Ixodidae) were collected during the present study. 

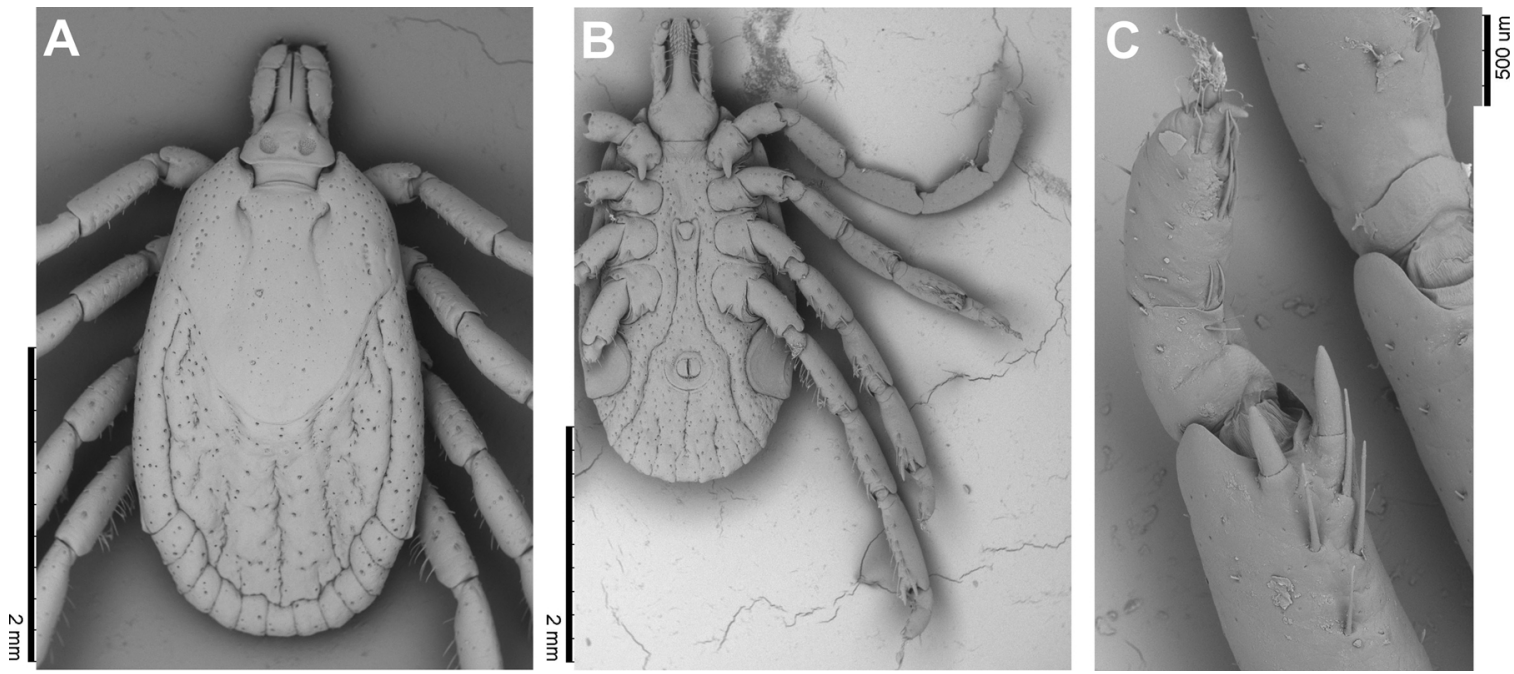

Fig. 2. A female specimen of Amblyomma maculatum from Ibagué-Tolima. (A) Dorsal view. (B) Ventral view. (C) Tarsus III showing two spurs.

Table 2

Ticks at different developmental stages (A: adults; N: nymphs; L: larvae) collected from different host species during 2014-2016 at different localities of Colombia.

\begin{tabular}{|c|c|c|c|}
\hline Tick species & Stage & Host & Localities $^{\mathrm{a}}$ \\
\hline Amblyomma dissimile & A & Bos taurus & 14 \\
\hline A. dissimile & $\mathrm{N}, \mathrm{L}$ & vegetation & 11 \\
\hline $\begin{array}{l}\text { Amblyomma } \\
\text { maculatum }\end{array}$ & A & $\begin{array}{l}\text { Canis lupus } \\
\text { familiaris }\end{array}$ & $9,14,15$ \\
\hline Amblyomma mixtum & $\mathrm{A}, \mathrm{N}$ & Bos taurus & $3,8,10,13$ \\
\hline A. mixtum & A & Equus asinus & 11 \\
\hline A. mixtum & A, $N$ & Equus caballus & $3,10,11$ \\
\hline A. mixtum & A,N,L & vegetation & 10,11 \\
\hline Amblyomma ovale & A & C. lupus familiaris & 14,15 \\
\hline Amblyomma varium & A & C. lupus familiaris & 14 \\
\hline Dermacentor nitens & $\mathrm{A}, \mathrm{N}$ & B. taurus & 1,3 \\
\hline D. nitens & $\mathrm{A}, \mathrm{N}$ & E. asinus & $6,11,14$ \\
\hline D. nitens & A,N,L & E. caballus & $1,3,6,10,11,14$ \\
\hline D. nitens & A & $\begin{array}{l}\text { Sus scrofa } \\
\text { domesticus }\end{array}$ & 3 \\
\hline Rhipicephalus microplus & A,N,L & B. taurus & $1,3-5,13,14,17$ \\
\hline R. microplus & A & C. lupus familiaris & 5 \\
\hline R. microplus & A & E. asinus & 6 \\
\hline $\begin{array}{l}\text { Rhipicephalus } \\
\text { sanguineus }\end{array}$ & A & B. taurus & 1,14 \\
\hline R. sanguineus & $\mathrm{A}, \mathrm{N}$ & C. lupus familiaris & $1-3,5,7,9,11,12,14-16,17$ \\
\hline R. sanguineus & A & E. caballus & 3,11 \\
\hline
\end{tabular}

${ }^{\text {a }}$ Locality numbers indicated in Table 1 and Fig. 1.

dosum Neumann, 1899, Amblyomma oblongoguttatum Koch, 1844, Amblyomma ovale Koch, 1844, Amblyomma pacae Aragão, 1911, Amblyomma rotundatum Koch, 184, Amblyomma sabanerae Stoll, 1894, Amblyomma scalpturatum Neumann, 1906, Amblyomma tapirellum Dunn, 1933, Amblyomma triste Koch, 1844, Amblyomma varium Koch, 1844, Haemaphysalis juxtakochi Cooley, 1946, Haemaphysalis leporispalustris (Packard, 1869), Ixodes boliviensis Neumann, 1904, Ixodes brunneus Kock, 1844, Ixodes fuscipes Kock, 1844, Ixodes lasallei Méndez Arocha and Ortiz, 1958, Ixodes luciae, Sénevet, 1940, Ixodes montoyanus Cooley, 1944, Ixodes pararicinus Keirans and Clifford, 1985, Ixodes tapirus Kohls, 1956, Ixodes tropicalis Kohls, 1956, Ixodes venezuelensis Kohls, 1953, Dermacentor nitens Neumann, 1897, Rhipicephalus microplus (Canestrini,
1887), and Rhipicephalus sanguineus (Latreille, 1806). In addition, there were reports from Colombia of Amblyomma parvum Aragão, 1908 (López and Parra, 1985; confirmed by Nava et al., 2017), Ixodes affinis Neumann, 1889 (Mattar and López-Valencia, 1998), and Dermacentor imitans Warburton, 1933 (Guglielmone et al., 2006). More recently, Nava et al. (2014) reevaluated the taxonomic status of $A$. cajennense and concluded that this taxon was actually represented by six valid species from which $A$. cajennense sensu stricto was not found to be present in Colombia in the examined samples, and only Amblyomma patinoi Labruna, Nava and Beati, 2014, and Amblyomma mixtum Koch, 1844 were confirmed for Colombia (Nava et al., 2014; Rivera-Páez et al., 2016). Finally, Apanaskevich and Bermúdez (2017) reported Ixodes bocatorensis Apanaskevich and Bermudez, 2017 from Colombia. Considering all these reports, the known tick fauna of Colombia currently includes 58 species (15 Argasidae and 43 Ixodidae), although as recently reported the presence of $I$. brunneus needs confirmation (Bermúdez et al., 2015). The present study was undertaken to expand our current knowledge of the biology of ticks in Colombia by collecting hard ticks (Ixodidae) from domestic animals and vegetation across 10 of Colombia's Departments.

\section{Materials and methods}

From August 2014 to May 2016, hard ticks were collected from domestic animals or vegetation in 10 Colombian Departments, encompassing 17 municipalities (Table 1, Fig. 1). Collected ticks were placed into plastic vials containing absolute ethanol and taken to the laboratory, where they were taxonomically identified based on current literature (Kohls, 1956; Jones et al., 1972; Estrada-Peña et al., 2005; Barros-Battesti et al., 2006; Martins et al., 2010; Nava et al., 2014; , 2015). The collection of specimens from animals was carried out under the Permit "Autoridad Nacional de Licencias Ambientales ANLA Resolución 1166 de octubre 9 de 2014".

In order to confirm morphological identifications, some specimens of each tick species were subjected to molecular taxonomic identification. DNA from individual ticks were extracted using the DNeasy Blood and Tissue kit (Qiagen, Chatsworth, California, USA) following the manufactureŕs protocol. The extracted DNA was tested by polymerase chain reaction (PCR) protocols to amplify fragments of at least one of the three following genes of the tick genome: primers 5'-GGT CAA CAA 
Table 3

Results of BLAST analysis searches in public data of the DNA sequences generated from ticks collected in the present study.

\begin{tabular}{|c|c|c|c|}
\hline \multirow[t]{2}{*}{ Tick species (localities ${ }^{\mathrm{a}}$ ) } & \multicolumn{3}{|c|}{ Closest identity (\%) in GenBank (accession number) according to the tick gene } \\
\hline & $\mathrm{COI}$ & 16S rRNA & ITS2 \\
\hline Amblyomma dissimile (11) & A. dissimile [KF200114] 99\% & N.A. & N.D. \\
\hline Amblyomma maculatum (14) & A. maculatum [KU302492] 99\% & A. maculatum [КТ037651] 99\% & N.D. \\
\hline Amblyomma maculatum (15) & A. triste [KU306582] 99\% & A. triste [KU284955] 99\% & N.D. \\
\hline Amblyomma maculatum (9) & N.D. & A. maculatum [KT037651] 100\% & N.D. \\
\hline Amblyomma mixtum (3) & N.D. & A. mixtum [KT820359] 97\% & N.D. \\
\hline Amblyomma mixtum $(3,8,10,13)$ & N.D. & A. mixtum [KT820359] $98 \%$ & A. cajennense $[\mathrm{JN} 866853]^{\#} 100 \%$ \\
\hline Amblyomma mixtum (8) & A. mixtum [KY595138] 99\% & N.D. & N.D. \\
\hline Amblyomma mixtum (11) & A. mixtum [KY595138] 99\% & N.D. & N.D. \\
\hline Amblyomma mixtum (13) & A. mixtum [KY595138] 99\% & N.D. & N.D. \\
\hline Amblyomma mixtum (10) & A. mixtum [KY595139] 100\% & N.D. & N.D. \\
\hline Amblyomma mixtum (11) & A. mixtum [KY595136] 99\% & N.D. & N.D. \\
\hline Amblyomma ovale $(14,15)$ & A. ovale [KF200080] 99\% & A. ovale [KU894383] 99\% & N.D. \\
\hline Dermacentor nitens (1) & D. nitens [КТ906190] 96\% & D. nitens [KY020994] 96\% & N.D. \\
\hline Dermacentor nitens $(3,6,10,11)$ & D. nitens [KT906188] 100\% & D. nitens [KY020994] 99\% & N.D. \\
\hline Dermacentor nitens (6) & D. nitens [KY441487] 99\% & N.D. & N.D. \\
\hline Rhipicephalus microplus $(3-5,13,14,17)$ & R. microplus [KT906181] 100\% & N.D. & N.D. \\
\hline Rhipicephalus microplus (5) & R. microplus [KT906181] 99\% & N.D. & N.D. \\
\hline Rhipicephalus microplus (1) & R. microplus [KY678120] 100\% & R. microplus [EU918176] 99\% & N.D. \\
\hline Rhipicephalus microplus $(1-5,13,14,17)$ & N.D. & R. microplus [EU918176] 100\% & N.D. \\
\hline Rhipicephalus sanguineus $(1-3,7,11,12,14-17)$ & N.D. & R. sanguineus [KY413787] 100\% & N.D. \\
\hline Rhipicephalus sanguineus (5) & N.D. & R. sanguineus [KY413787] 99\% & N.D. \\
\hline Rhipicephalus sanguineus $(1,14,16)$ & N.D. & N.D. & R. sanguineus [KY945496] 99\% \\
\hline Rhipicephalus sanguineus $(3,15)$ & N.D. & N.D. & R. sanguineus [JQ625707] 99\% \\
\hline Rhipicephalus sanguineus (11) & N.D. & N.D. & R. sanguineus [KF499537] 99\% \\
\hline Rhipicephalus sanguineus (7) & N.D. & N.D. & R. sanguineus [AF271283] 99\% \\
\hline Rhipicephalus sanguineus (14) & N.D. & N.D. & R. sanguineus [KF499537] 99\% \\
\hline Rhipicephalus sanguineus (2) & N.D. & N.D. & R. sanguineus [KF499537] 99\% \\
\hline Rhipicephalus sanguineus $(3,7,11,14)$ & N.D. & N.D. & R. sanguineus [KF499537] 99\% \\
\hline Rhipicephalus sanguineus (11) & N.D. & N.D. & R. turanicus [KF958425] 99\% \\
\hline Rhipicephalus sanguineus (1) & N.D. & N.D. & R. turanicus [KF499532] 99\% \\
\hline Rhipicephalus sanguineus (11) & N.D. & N.D. & R. turanicus [KF958425] 99\% \\
\hline
\end{tabular}

N.D.: not done.

N.A.: sequences not available in GenBank.

\# This sequence was deposited in GenBank as A. cajennense; however, according to Nava et al. (2014), this sequence corresponds to A. mixtum.

${ }^{a}$ Locality numbers indicated in Table 1 and Fig. 1.

ATC ATA AAG ATA TTG G-3' and 5'-TAA ACT TCA GGG TGA CCA AAA AAT CA- $3^{\prime}$, targeting a $\approx 700$-bp fragment of the mitochondrial cytochrome c oxidase subunit I gene (COI) (Folmer et al., 1994); primers 5'-CTG CTC AAT GAT TTT TTA AAT TGC TGT GG-3' and 5'-CCG GTC TGA ACT CAG ATC AAG T-3, targeting a $\approx 460$-bp fragment of the mitochondrial 16S rDNA gene (Norris et al., 1996); and primers 5'-CCA TCG ATG TGA AYT GCA GGA CA-3' (Zahler et al., 1995) and 5'-GTG AAT TCT ATG CTT AAA TTC AGG GGG T-3', which amplifies a $\approx 1100$ bp fragment that includes the entire second internal transcribed spacer (ITS2) region of the nuclear rRNA region (Mclain et al., 1995). In addition, specimens of the following species collected in Brazil were processed by the above PCR protocols in order to obtain DNA sequences for inclusion in the phylogenetic analyses: A. cajennense s.s. from Governador Jorge Teixeira, Rondônia state, A. sculptum from Pirassununga, São Paulo state, Amblyomma triste from Paulicéia, São Paulo state, $R$. sanguineus s.l. from Chapada Gaúcha, Minas Gerais state, and $R$. sanguineus s.l. from São Paulo City, São Paulo state.

PCR products were purified with the QIAquick PCR purification kit (Qiagen), and sent to Macrogen Inc. (South Korea) for DNA sequencing. The sequenced fragments were evaluated and edited using Geneious Trial v8.14 (Drummond et al., 2009) and Sequencher 4.1 (Gene Codes Corporation, Ann Arbor, Michigan, USA). In addition, the sequences were searched by MegaBlast against the public databases and deposited in GenBank and Barcode of Life Data Systems (BOLD). The sequences for each gene were aligned using ClustalW (Thompson et al., 1997), included in the program MEGA version 7 (Tamura et al., 2013). Intraspecific nucleotide divergences were estimated with the program MEGA, using the Kimura 2-Parameter distance model (K2P; Kimura, 1980). Species confirmation was carried out through a similarity analysis based on Maximum Likelihood (ML), with the K2P model and 1000 bootstrap replications, using the program MEGA. Each alignment included different sequences from GenBank, as stated by their accession numbers in the trees.

\section{Results}

A total of 1745 tick specimens (1543 adults, 111 nymphs, and 91 larvae) were collected from 85 individual hosts, including 28 cattle (Bos taurus), 26 domestic dogs (Canis lupus familiaris), 25 horses (Equus caballus), 5 donkeys (Equus asinus), and 1 domestic pig (Sus scrofa domesticus), with an additional 3 tick samples collected from vegetation (Table S1). Ticks were morphologically identified to 8 species: $A$. dissimile, A. maculatum (Fig. 2), A. mixtum, A. ovale, A. varium, D. nitens, $R$. microplus, and $R$. sanguineus sensu lato (s.l.). Hosts and collection localities for each tick species are shown in Table 2. Overall, 5 tick species were recorded on cattle (A. dissimile, A. mixtum, D. nitens, $R$. microplus, $R$. sanguineus s.1.), 5 on dogs (A. maculatum, A. ovale, A. varium, R. microplus, $R$. sanguineus s.l.), 3 on horses (A. mixtum, D. nitens, $R$. 


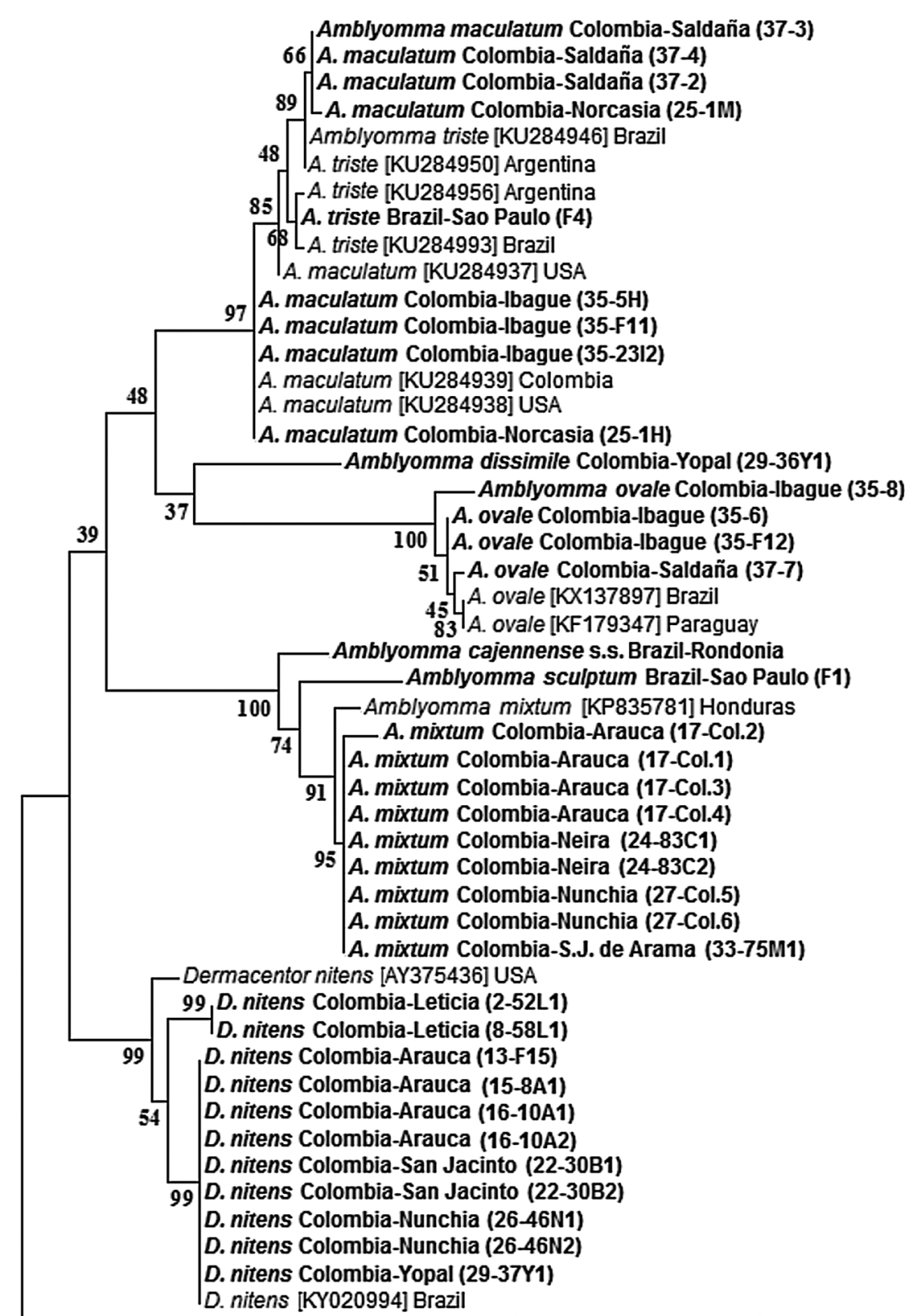

Fig. 3. Maximum Likelihood (ML) tree using sequences of the mitochondrial 16S rDNA gene partial sequences of tick specimens collected in the present study (in bold) and sequences from GenBank (accession numbers in brackets). Numbers at nodes are bootstrap support values. The sequence of Ornithodoros rostratus was used as outgroup.

Ornithodoros rostratus [DQ295780]

sanguineus s.1.), 3 on donkeys (A. mixtum, D. nitens, R. microplus), and 1 on pig (D. nitens).

Partial sequences of the tick 16S rRNA and/or COI and/or ITS2 genes were generated for tick specimens of all collected tick species (Table 3), except for A. varium. Phylogenetical analyses based on $16 \mathrm{~S}$ rRNA and COI partial sequences placed $A$. maculatum from Colombia mixed within a clade composed by sequences of $A$. maculatum from the United States and Colombia, and Amblyomma triste from Brazil and Argentina (Figs. 3 and 4). Moreover, sequences from A. ovale grouped with corresponding sequences of $A$. ovale from Brazil and Paraguay (Fig. 3), or Panama (Fig. 4); sequences of $D$. nitens grouped with $D$. nitens from the United States and Brazil (Fig. 3), or Colombia and Panama (Fig. 4); a sequence of $A$. dissimile grouped with $A$. dissimile from Brazil (Fig. 4); and sequences of $A$. mixtum grouped with A. mixtum from Honduras (Fig. 3) or Colombia, Ecuador and Panama (Fig. 4). These results for $A$. mixtum were corroborated by the ITS2 phylogenetic analysis, in which our sequences of $A$. mixtum grouped with $A$. mixtum sequences from Colombia, Costa Rica, Mexico and the United States (Fig. 5).

All 16S rRNA sequences of Colombian $R$. sanguineus s.l. generated in the present study grouped with $R$. sanguineus s.l. from Brazil, Colombia, Thailand, and South Africa (Fig. 6). In the phylogenetic analysis 


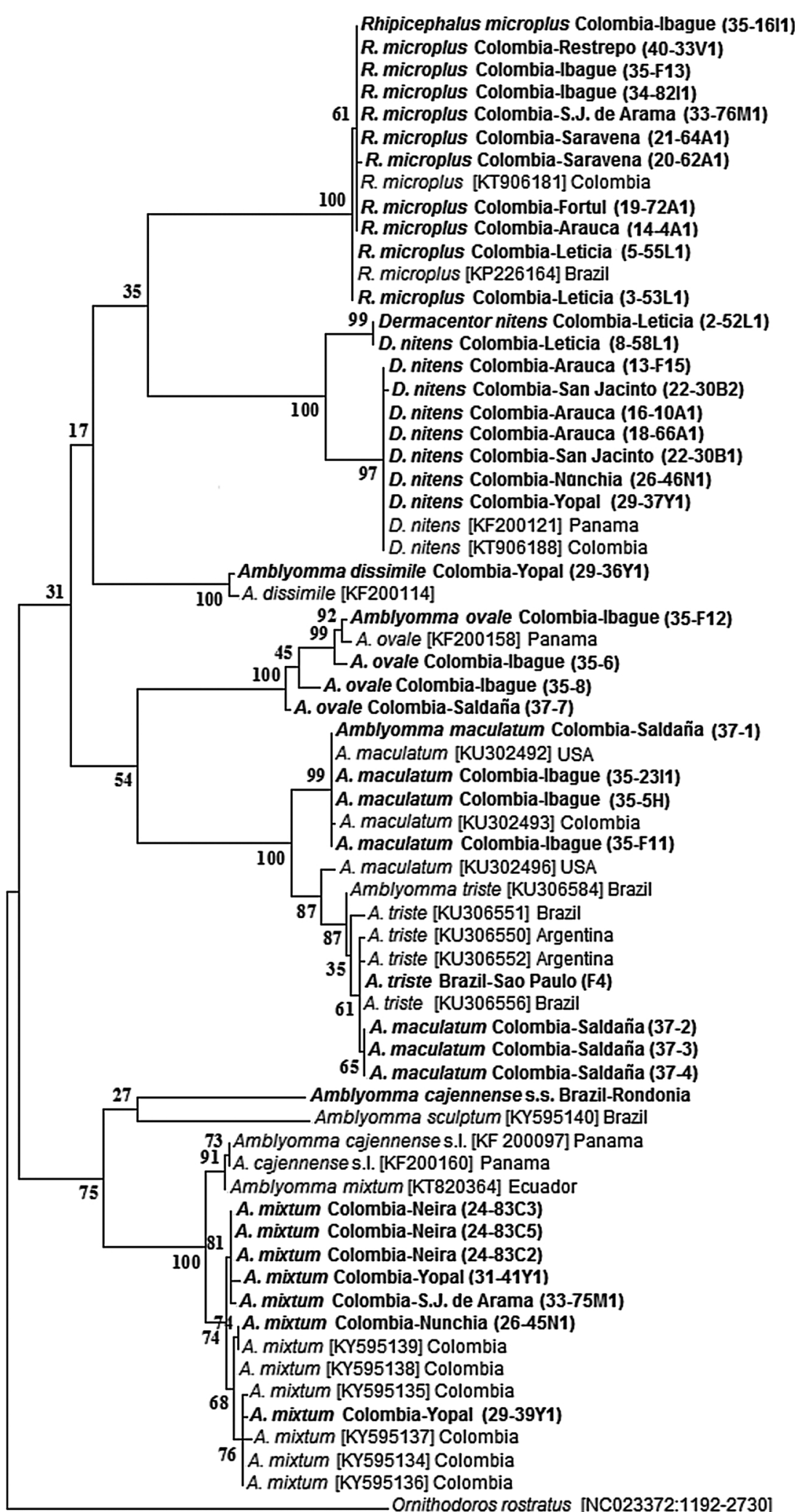

Fig. 4. Maximum Likelihood (ML) tree using sequences of the mitochondrial cytochrome c oxidase subunit I (COI) gene partial sequences of tick specimens collected in the present study (in bold) and sequences from GenBank (accession numbers in brackets). Numbers at nodes are bootstrap support values. The sequence of Ornithodoros rostratus was used as outgroup. 


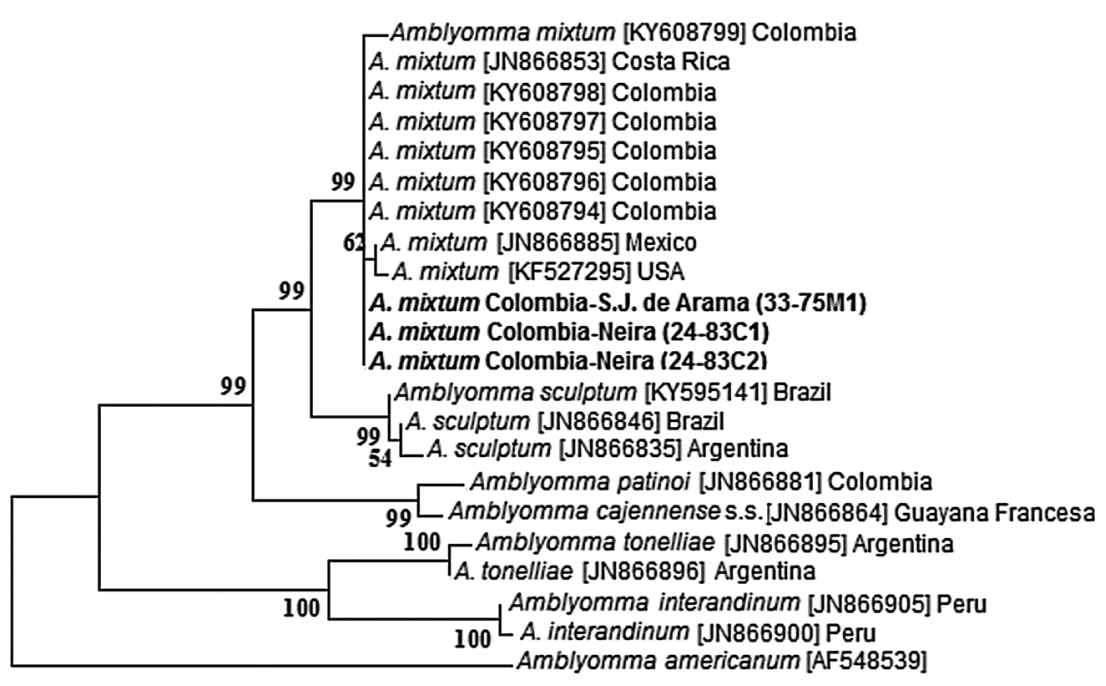

Fig. 5. Maximum Likelihood (ML) tree using sequences of the second internal transcribed space (ITS2) gene partial sequences of tick specimens collected in the present study (in bold) and sequences from GenBank (accession numbers in brackets). Numbers at nodes are bootstrap support values. The sequence of Amblyomma americanum was used as outgroup. inferred by the ITS2 gene of $R$. sanguineus s.l. ticks, the Colombian specimens grouped in a large clade composed by sequences from tropical countries such as Costa Rica, Honduras, Brazil, Colombia and Thailand, but also by sequences from Australia, Egypt, and India (Fig. 7). Regarding our specimens of $R$. microplus, their 16S rRNA sequences grouped in a clade with $R$. microplus from Argentina (Fig. 6), while their $\mathrm{COI}$ sequences grouped with sequences of $R$. microplus from Brazil and Colombia (Fig. 4).

GenBank nucleotide sequence accession numbers for the DNA sequences obtained in the current study are: MF351562-MF351603, MF353094-MF353129 for the mitochondrial rRNA 16S gene; MF363053-MF363093 for the mitochondrial COI gene, and MF353130MF353154 for nuclear ITS2 gene. Voucher tick specimens were deposited at the tick collection "Coleção Nacional de Carrapatos Danilo Gonçalves Saraiva" - CNC (University of São Paulo, São Paulo, Brazil).

\section{Discussion}

All tick species collected in the present study were previously reported from Colombia (Guglielmone et al., 2003; Rivera-Páez et al., 2016). Similarly, the tick-host associations in our study agree with previous records (López and Parra 1985; Need et al., 1991; Rivera-Páez et al., 2016; Nava et al., 2017), with the exception that we report the first confirmed collection of $A$. varium from dog.

From $7 \mathrm{~A}$. maculatum specimens from Colombia, we generated 3 distinct haplotypes for the 16S rRNA gene, and 2 for COI. In each of the trees inferred from these two genes, the Colombian specimens formed a large clade with GenBank sequences of $A$. maculatum and $A$. triste. Noteworthy, while some Colombian specimens grouped with $A$. maculatum from the United States, other Colombian specimens grouped with A. triste from Brazil, for both genes. At first sight, these results could indicate that some Colombian specimens could represent the taxon $A$. triste; however, we retained these specimens as A. maculatum because their morphology was compatible with A. maculatum (two spurs on tarsi II-IV) (Fig. 2) rather than A. triste (one spur on tarsi II-IV), as stated in the literature (Kohls, 1956; Estrada-Peña et al., 2005). Further studies are required to elucidate the taxonomic status of $A$. maculatum and $A$. triste, since the taxonomic separation of these two species is yet to be resolved, with the possibility that they might be conspecific (Nava et al., 2017).

From up to $9 \mathrm{~A}$. mixtum specimens from Colombia, we generated 2 distinct haplotypes for the 16S rRNA gene, 5 for COI, and 1 for ITS2. In each of the trees inferred from these three genes, the Colombian specimens grouped with GenBank sequences of $A$. mixtum, well separated from all other members of the $A$. cajennense species complex. These results corroborate a recent study that confirmed the presence of $A$. mixtum in Colombia (Rivera-Páez et al., 2016). However, whereas this previous report consisted of specimens from the Departments of Arauca and Casanare (northeastern Colombia), the present records confirm the presence of $A$. mixtum in these two Departments and expand it to two other Departments, Caldas and Meta (central Colombia). These results indicate that the distribution of A. mixtum in Colombia may be much broader than currently known.

From up to $30 R$. sanguineus s.l. specimens from Colombia, we generated 2 distinct haplotypes for the 16S rRNA gene, and 10 for ITS2. In the tree inferred from the 16S rRNA gene, all Colombian specimens grouped with $R$. sanguineus specimens from Brazil and Colombia, which represent the so called "tropical species", as reported elsewhere (Burlini et al., 2010; Moraes-Filho et al., 2011; Dantas-Torres et al., 2013). These 30 R. sanguineus s.l. specimens were collected in 8 Departments of Colombia (Amazonas, Antioquia, Arauca, Caldas, Casanare, Cundinamarca, Tolima, Valle del Cauca), whereas the previous reports represented specimens from the Departments of Cordoba (Moraes-Filho et al., 2011), Antioquia, and Valle del Cauca (Dantas-Torres et al., 2013). These results indicate that the taxon $R$. sanguineus s.l. is possibly represented in Colombia solely by the "tropical species", which seems to be widespread in the country. In contrast to the 16S rRNA gene, the tree inferred from the ITS-2 gene did not segregate the Colombian specimens from specimens from other parts of the world. This inconclusive analysis is supported by the study of Latrofa et al. (2013), who demonstrated that the ITS-2 gene is not reliable for identification of ticks within the Rhipicephalus genus, especially among specimens of $R$. sanguineus s.l.

From up to $11 R$. microplus specimens from Colombia, we generated 2 distinct haplotypes for the 16S rRNA gene, and 3 for COI. In the trees inferred from these two genes, the Colombian specimens formed a clade 


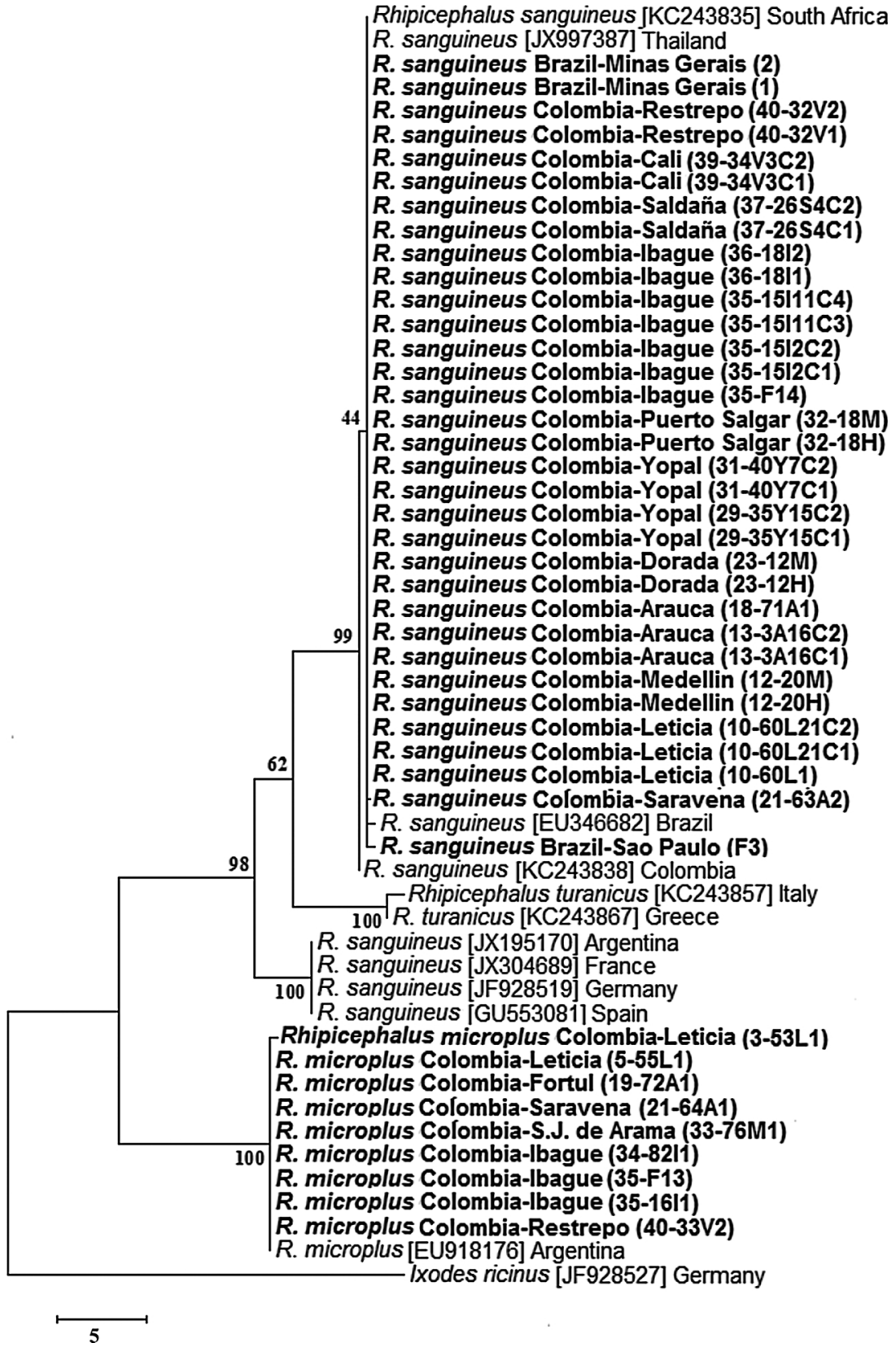

Fig. 6. Maximum Likelihood (ML) tree using sequences of the mitochondrial 16S rDNA gene partial sequences of tick specimens collected in the present study (in bold) and sequences from GenBank (accession numbers in brackets). Numbers at nodes are bootstrap support values. The sequence of Ixodes ricinus was used as outgroup. with sequences from Argentina and Brazil, which correspond to bona fide records of $R$. microplus according to the studies of Labruna et al. (2009) and Estrada-Peña et al. (2012), who re-evaluated the taxonomic status of $R$. microplus. Regarding the trees that included $D$. nitens sequences, it was interesting to note some polymorphism in their $16 \mathrm{~S}$ rRNA or COI sequences, which in both cases resulted in a clade that separated the sequences of Leticia (Amazonas Department) from the other Colombian Departments (Arauca, Bolívar, Casanare, Tolima), although we could not detect significant morphological differences between these specimens (data not shown). Finally, the relatively high polymorphism between the sequences of $A$. ovale for the two mitochondrial genes (Figs. 3 and 4) is corroborated by a study in Brazil, where four distinct haplotypes of $A$. ovale, differing up to $3.9 \%$, were generated from a single region (Martins et al., 2016).

This study provides new records for 8 tick species parasitizing domestic animals in Colombia, including species with veterinary and medical importance in the Neotropical region, such as $R$. microplus, $R$. sanguineus, D. nitens, A. mixtum, and A. maculatum (Guglielmone et al., 2003; Nava et al., 2014, 2017). Most of these species have gone through extensive taxonomic changes or contestations over the last decade (Estrada-Peña et al., 2012; Nava et al., 2014, 2015, 2017). For this reason, phylogenetic analyses of specimens from poorly explored sites such as Colombia are crucial for our growing knowledge of tick systematics in the Neotropical region, where ticks associated with domestic animals are vectors of a number of pathogens to animals and humans (Nava et al., 2017). 


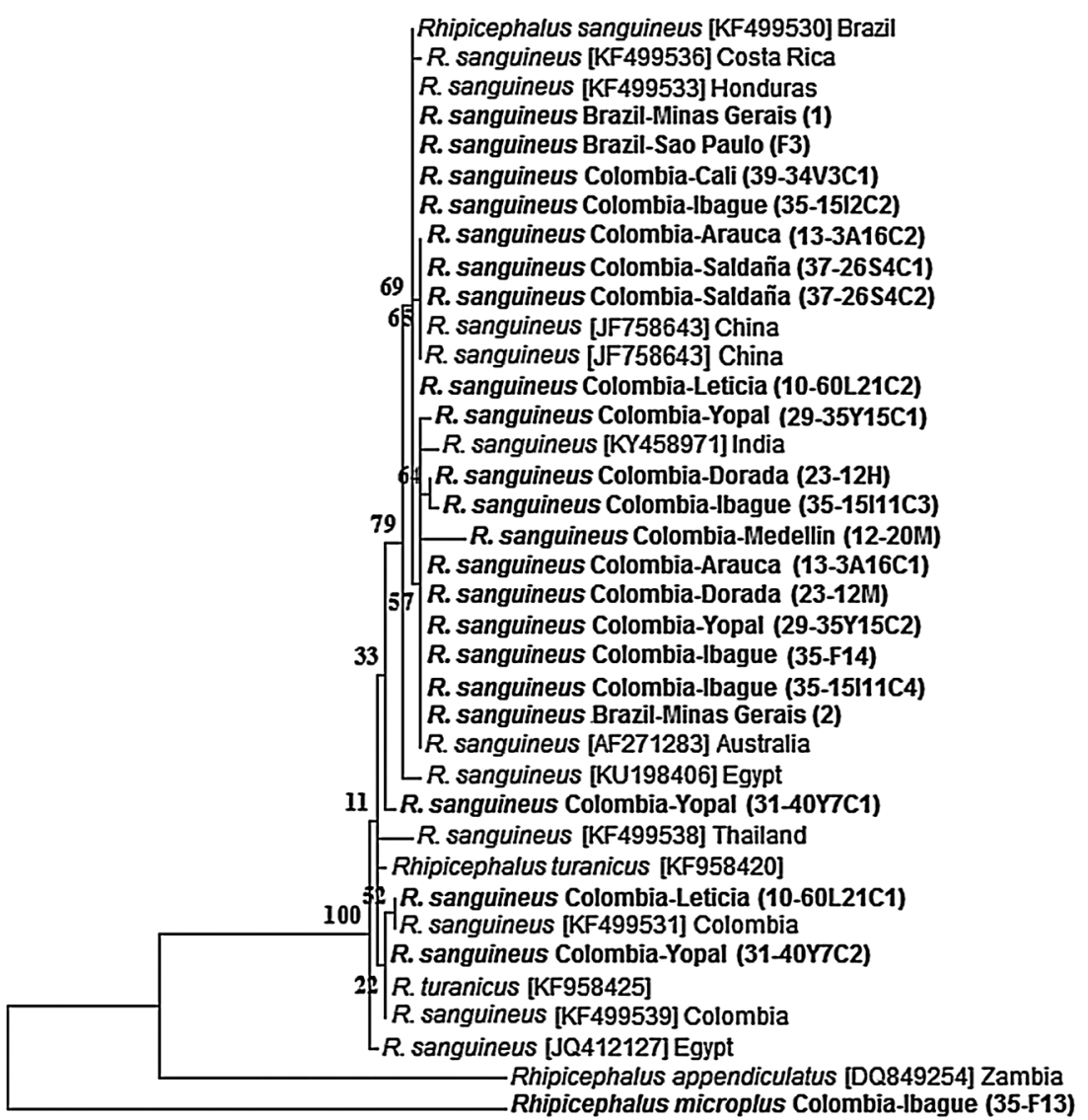

Fig. 7. Maximum Likelihood (ML) tree using sequences of the second internal transcribed space (ITS2) gene partial sequences of tick specimens collected in the present study (in bold) and sequences from GenBank (accession numbers in brackets). Numbers at nodes are bootstrap support values. The sequence of Rhipicephalus microplus was used as outgroup.

\section{Acknowledgments}

We are grateful for the assistance provided by the AUIP-Asociación Universitaria Iberoamericana de Postgrado, CNPq-Conselho Nacional de Desenvolvimento Científico e Tecnológico, Vicerrectoría de Investigaciones y Posgrados (Universidad de Caldas), Unidad Administrativa Especial de Salud de Arauca - Programa ETV Gobernación de Arauca (Colombia). The project was funded by COLCIENCIAS (112765740609; execution contract: 684 of 2014).

\section{Appendix A. Supplementary data}

Supplementary data associated with this article can be found, in the online version, at http://dx.doi.org/10.1016/j.ttbdis.2017.10.008.

\section{References}

Apanaskevich, D.A., Bermúdez, S.E., 2017. Description of a new species of Ixodes Latreille, 1795 (Acari: Ixodidae) and redescription of I. lasallei Múndez \& Ortiz, 1958, parasites of agoutis and pacas (Rodentia: Dasyproctidae, Cuniculidae) in Central and South America. Syst. Parasitol. 94, 463-475.

Ash, A., Elliot, A., Godfrey, S., Burmej, H., Abdad, M.Y., Northover, A., Wayne, A., Morris, K., Clode, P., Lymbery, A., Thompson, R.C., 2017. Morphological and molecular description of Ixodes woyliei n. sp. (Ixodidae) with consideration for co-extinction with its critically endangered marsupial host. Parasite Vectors 10, 70.

Barros-Battesti, D.M., Arzua, M., Bechara, G.H., 2006. Carrapatos de importância médicoveterinária da Região Neotropical: um guia ilustrado para identificação de espécies. Vox/ICTTD-3/Butantan, São Paulo 223 p.

Bermúdez, S.E., Torres, S., Aguirre, Y., Domínguez, L., Bernal Veja, J.A., 2015. A review of Ixodes (Acari Ixodidae) parasitizing wild birds in Panama, with the first records of Ixodes auritulus and Ixodes bequaerti. Syst. Appl. Acarol. 20, 847-853.
Burlini, L., Teixeira, K.R., Szabó, M.P., Famadas, K.M., 2010. Molecular dissimilarities of Rhipicephalus sanguineus (Acari: Ixodidae) in Brazil and its relation with samples throughout the world: is there a geographical pattern? Exp. Appl. Acarol. 50, 361-374.

Chitimia-Dobler, L., DE Araujo, B.C., Ruthensteiner, B., Pfeffer, T., Dunlop, J.A., 2017. Amblyomma birmitum a new species of hard tick in Burmese amber. Parasitolology 6 (June), 1-8. http://dx.doi.org/10.1017/S0031182017000853.

Dantas-Torres, F., Latrofa, M.S., Annoscia, G., Giannelli, A., Parisi, A., Otranto, D., 2013. Morphological and genetic diversity of Rhipicephalus sanguineus sensu lato from the New and Old Worlds. Parasite Vectors 6, 213.

Drummond, A.J., Ashton, B., Cheung, M., Heled, J., Kearse, M., Moir, R., Stones, H.S., Thierer, T., Wilson, A., 2009. Geneious 8. pp. 14. disponible en: http://www. geneious.com.

Estrada-Peña, A., Venzal, J.M., Mangold, A.J., Cafrune, M.M., Guglielmone, A.A., 2005. The Amblyomma maculatum Koch, 1844 (Acari Ixodidae: Amblyomminae) tick group: diagnostic characters, description of the larva of A. parvitarsum Neumann, 1901, $16 \mathrm{~S}$ rDNA sequences, distribution and hosts. Syst. Parasitol. 60, 99-112.

Estrada-Peña, A., Venzal, J.M., Nava, S., Mangold, A., Guglielmone, A.A., Labruna, M.B., de la Fuente, J., 2012. Reinstatement of Rhipicephalus (Boophilus) australis (Acari: Ixodidae) with redescription of the adult and larval stages. J. Med. Entomol. 49, 794-802.

Folmer, O., Black, M., Hoeh, W., Lutz, R., Vrijenhoek, R., 1994. DNA primers for amplification of mitochondrial cytochrome c oxidase subunit I from diverse metazoan invertebrates. Mol. Mar. Biol. Biotechnol. 3, 294-299.

Guglielmone, A.A., Estrada-Peña, A., Keirans, J.E., Robbins, R.G., 2003. Ticks (Acari: Ixodida) of the neotropical zoogeographic region. In: Special Publication of the Integrated Consortium on Ticks and Tick-Borne Diseases-2. Houten (The Netherlands): Atalanta.

Guglielmone, A.A., Beati, L., Barros-Battesti, D.M., Labruna, M.B., Nava, S., Venzal, J.M., Mangold, A.J., Szabó, M.P., Martins, J.R., González-Acuña, D., Estrada-Peña, A., 2006. Ticks (Ixodidae) on humans in South America. Exp. Appl. Acarol. 40, 83-100.

Guo, T., Sun, Y., Xu, G., Durden, L., 2017. Ixodes kangdingensis (Acari: Ixodidae), a new species from the Siberian weasel, Mustela sibirica (Carnivora: mustelidae) in China. Parasitol. Open 3. http://dx.doi.org/10.1017/pao.2017.7.

Hornok, S., Görföl, T., Estók, P., Tu, V.T., Kontschán, J., 2016. Description of a new tick species, Ixodes collaris n. sp. (Acari: Ixodidae), from bats (Chiroptera: hipposideridae, 
Rhinolophidae) in Vietnam. Parasite Vectors 9, 332

Jones, E.K., Clifford, C.M., Keirans, J.E., Kohls, G.M., 1972. The ticks of Venezuela (Acarina: Ixodoidea) with a key to the species of Amblyomma in the western hemisphere. Brigham Young Univ. Sci. Bull. Biol. Ser. 17, 1-40.

Kimura, M., 1980. A simple method for estimating evolutionary rate of base substitutions through comparative studies of nucleotide sequences. J. Mol. Evol. 16, 111-120.

Kohls, G.M., 1956. Concerning the identity of Amblyomma maculatum, A. tigrinum, A triste, and A. ovatum of Koch, 1844. In: Washington. Proc. Entomol. Soc. 58. pp. 143-147.

López, G., Parra, D., 1985. Amblyomma neumanni, Ribaga 1902: Primera comprobación en Colombia y claves para las especies de Amblyomma. Rev. Inst. Colombiano Agropec. 20, 152-162.

Labruna, M.B., Naranjo, V., Mangold, A.J., Thompson, C., Estrada-Peña, A., Guglielmone, A.A., Jongejan, F., de la Fuente, J., 2009. Allopatric speciation in ticks: genetic and reproductive divergence between geographic strains of Rhipicephalus (Boophilus) microplus. BMC Evol. Biol. 9, 46.

Labruna, M.B., Nava, S., Marcili, A., Barbieri, A.R., Nunes, P.H., Horta, M.C., Venzal, J.M., 2016. A new argasid tick species (Acari: Argasidae) associated with the rock cavy, Kerodon rupestris wied-neuwied (Rodentia: caviidae), in a semiarid region of Brazil. Parasite Vectors 9, 511.

Latrofa, M.S., Dantas-Torres, F., Annoscia, G., Cantacessi, C., Otranto, D., 2013. Comparative analyses of mitochondrial and nuclear genetic markers for the molecular identification of Rhipicephalus spp. Infect. Genet. 20, 422-427.

Martins, T.F., Onofrio, V.C., Barros-Battesti, D.M., Labruna, M.B., 2010. Nymphs of the genus Amblyomma (Acari Ixodidae) of Brazil: descriptions, redescriptions, and identification key. Ticks Tick Borne Dis. 1, 75-99.

Martins, T.F., Peres, M.G., Costa, F.B., Bacchiega, T.S., Appolinario, C.M., Antunes, J.M.A.P., Vicente, A.F., Megid, J., Labruna, M.B., 2016. In: Ciência Rural, Santa Maria. Ticks Infesting Wild Small Rodents in Three Areas of the State of São Paulo Brazil 46. pp. 871-875.

Mattar, S., López-Valencia, G., 1998. Searching for Lyme disease in Colombia: a preliminary study on the vector. J. Med. Entomol. 35, 324-326.

Mclain, D.K., Wesson, D.M., Oliver, J.H., Collins, F.H., 1995. Variation in ribosomal DNA internal transcribed spaces 1 among eastern populations of Ixodes scapularis (Acari: Ixodidae). J. Med. Entomol. 32, 353-360.

Moraes-Filho, J., Marcili, A., Nieri-Bastos, F.A., Richtzenhain, L.J., Labruna, M.B., 2011. Genetic analysis of ticks belonging to the Rhipicephalus sanguineus group in Latin America. Acta Trop. 117, 51-55.

Muñoz-Leal, S., Venzal, J.M., González-Acuña, D., Nava, S., Lopes, M.G., Martins, T.F., Figueroa, C., Fernández, N., Labruna, M.B., 2016. A new species of Ornithodoros
(Acari: Argasidae) from desert areas of Northern Chile. Ticks Tick Borne Dis. 7, 901-910.

Muñoz-Leal, S., Toledo, L.F., Venzal, J.M., Marcili, A., Martins, T.F., Acosta, I.C.L., Pinter, A., Labruna, M.B., 2017. Description of a new soft tick species (Acari: Argasidae: Ornithodoros) associated with stream-breeding frogs (Anura: Cycloramphidae: Cycloramphus) in Brazil. Ticks Tick Borne Dis. 8, 682-692.

Nava, S., Beati, L., Labruna, M.B., Cáceres, A.G., Mangold, A.J., Guglielmone, A.A., 2014 Reassessment of the taxonomic status of Amblyomma cajennense (Fabricius, 1787) with the description of three new species, Amblyomma tonelliae n. sp., Amblyomma interandinum n. sp. and Amblyomma patinoi n. sp., and reinstatement of Amblyomma mixtum Koch, 1844, and Amblyomma sculptum Berlese, (Ixodida: Ixodidae). Ticks Tick Borne Dis. 5, 252-276.

Nava, S., Estrada-Peña, A., Petney, T., Beati, L., Labruna, M.B., Szabó, M.P., Guglielmone, A.A., 2015. The taxonomic status of Rhipicephalus sanguineus (Latreille, 1806). Vet. Parasitol. 208, 2-8.

Nava, S., Venzal, J.M., González-Acuña, D.G., Martins, T.F., Guglielmone, A.A., 2017. Ticks of the Southern Cone of America: Diagnosis, Distribution, and Hosts with Taxonomy, Ecology and Sanitary Importance, 1st ed. Elsevier, London, San Diego, Cambridge 375p.

Need, J.T., Dale, W.E., Keirans, J.M., Dasch, G.A., 1991. Annotated list of ticks (Acari: Ixodidae: Argasidae) reported in Peru: distribution, hosts, and bibliography. J. Med. Entomol. 28, 590-597.

Norris, D.E., Klompen, J.S.H., Keirans, J.E., Black, W.C., 1996. Population genetics of Ixodes scapularis (Acari: Ixodidae) based on mitochondrial $16 \mathrm{~S}$ and $12 \mathrm{~S}$ genes. J. Med. Entomol. 33, 78-89.

Osorno-Mesa, E., 1940. Las garrapatas de la República de Colombia. Revista de la Academia Colombiana de Ciencias Exactas. Físico-Químicas y Naturales 4, 6-24.

Rivera-Páez, F.A., Labruna, M.B., Martins, T.F., Sampieri, B.R., Camargo-Mathias, M.I., 2016. Amblyomma mixtum Koch, 1844 (Acari: Ixodidae): First record confirmation in Colombia using morphological and molecular analyses. Ticks Tick Borne Dis. 7, $842-848$.

Tamura, K., Stecher, G., Peterson, D., Filipski, A., Kumar, S., 2013. MEGA 6: molecular evolutionary genetics analysis version 6.0. Mol. Biol. Evol. 30, 2725-2729.

Thompson, J.D., Gibson, T.J., Plewniak, F., Jeanmougin, F., Higgins, D.G., 1997. The CLUSTAL X windows interface: flexible strategies for multiple sequence alignment aided by quality analysis tools. Nucleic Acids Res. 25, 4876-4882.

Zahler, M., Gothe, R., Rinder, H., 1995. Genetic evidence against a morphologically suggestive conspecificity of Dermacentor reticulatus and D. marginatus (Acari: Ixodidae). Int. J. Parasitol. 25, 1413-1419. 